\title{
Influence of calcitonin gene-related peptide on model mice with acute pancreatitis
}

\section{[Kalsitonin geniyle ilişkili peptidin akut pankreatitli model fareler üzerindeki etkisi]}

https://doi.org/10.1515/tjb-2020-0086

Received April 19, 2020; accepted December 26, 2020; published online March 1, 2021

\section{Abstract}

Objectives: To establish model mice with acute pancreatitis (AP) and study influence of calcitonin gene-related peptide (CGRP) on AP.

Methods: The model mice with AP were firstly established by intraperitoneal injection of successive six doses of caerulein $(100 \mu \mathrm{g} / \mathrm{kg})$ and one dose of lipopolysaccharide $(10 \mathrm{mg} / \mathrm{kg})$. The intraperitoneal injection of CGRP $(100 \mu \mathrm{g} /$ $\mathrm{kg}$ ) was performed to investigate influence of CGRP on AP, mainly involving the determination of amylase activity and the expression of CGRP and $\mathrm{CD}_{20} \mathrm{O}^{+} \mathrm{B}$ lymphocytes.

Results: CGRP on mice with AP could significantly reduce the severity of pancreatic pathological injury, the activity of amylase and the expression of $\mathrm{CD}^{2} \mathrm{O}^{+} \mathrm{B}$ lymphocytes. CGRP was significantly expressed in pancreatic tissue with $\mathrm{AP}$, but CGRP receptor antagonist down-regulated the expression of CGRP and increased the number of $\mathrm{CD}_{2} \mathrm{O}^{+} \mathrm{B}$ lymphocytes, confirming the protective effect of CGRP on pancreatic tissue.

Conclusions: We preliminarily conclude that CGRP could significantly improve the pancreatic lesions and inflammatory infiltration of pancreas in mice with $\mathrm{AP}$, and reduce the damage of pancreatic acinar cells, by mainly increasing blood flow and blood flow velocity of pancreas to improve

*Corresponding author: Wei Lin, Gastrointestinal Surgery, Affiliated Hospital of Putian University, 999 Dongzhen Road, Putian, Fujian, 351100, China; E-mail: linwbj@sina.com

Jianxiong Hu, Yanya Lin, Shijun Chen and Yangfang Cai, Intensive Care Unit (ICU), Affiliated Hospital of Putian University, Putian, China. https://orcid.org/0000-0003-0810-2696 (J. Hu)

Zhiwei Chen, Department of Pathology, Affiliated Hospital of Putian University, Putian, China

Ә Open Access. (C) 2021 Jianxiong Hu et al., published by De Gruyter. (cc) BY International License. the pancreatic microcirculation and effectively reducing the permeability of the microvessels to decrease the pathological damage degree of AP.

Keywords: amylase; CGRP receptor antagonist; inflammatory infiltration; pancreatic microcirculation; trypsin.

\section{öz}

Amaç: Akut pankreatit (AP) olan model fareler oluşturmak ve kalsitonin geniyle ilişkili peptidin (CGRP) AP üzerindeki etkisini incelemek.

Yöntemler: AP’li model fareler, ilk olarak arka arkaya altı doz caerulein $(100 \mu \mathrm{g} / \mathrm{kg})$ ve bir doz lipopolisakkarit $(10 \mathrm{mg} / \mathrm{kg})$ intraperitoneal enjeksiyonla oluşturuldu. CGRP'nin (100 ug/kg) intraperitoneal enjeksiyonu, esas olarak amilaz aktivitesinin belirlenmesi ve CGRP ve CD20 + B lenfositlerinin ekspresyonunu içeren CGRP'nin AP üzerindeki etkisini araştırmak için gerçekleştirildi.

Bulgular: AP'li farelerdeki CGRP, pankreas patolojik hasarının şiddetini, amilaz aktivitesini ve CD20 + B lenfositlerinin ekspresyonunu önemli ölçüde azaltabilir. CGRP, AP'li pankreas dokusunda önemli ölçüde eksprese edildi, ancak CGRP reseptör antagonisti, CGRP ekspresyonunu aşağı regüle etti ve CD20 + B lenfositlerinin sayısını artırarak, CGRP'nin pankreas dokusu üzerindeki koruyucu etkisini doğruladı.

Sonuç: CGRP'nin AP'li farelerde pankreas lezyonlarını ve enflamatuar infiltrasyonunu önemli ölçüde iyileştirebileceği ve pankreas mikrosirkülasyonunu iyileştirmek için pankreasın kan akışını ve kan akış hızını artırarak ve AP'nin patolojik hasar derecesini azaltmak için etkili bir şekilde mikrodamarların geçirgenliğini azaltarak pankreas asiner hücrelerinin hasarını azaltabileceği sonucuna varıoruz.

Anahtar Kelimeler: amilaz; CGRP reseptör antagonisti; inflamatuar infiltrasyon; pankreas mikrosirkülasyonu; tripsin. 


\section{Introduction}

Pancreas lying in the upper abdomen behind the stomach is an exocrine organ that makes and secretes digestive enzymes into the intestine, and also an endocrine organ that makes and secretes hormones into the blood to control energy metabolism and storage throughout the body [1]. As we all know, diseases associated with pancreatic exocrine function mainly include acute and chronic pancreatitis. Among them, acute pancreatitis (AP) can cause the pancreas itself to be digested, and it is believed that the premature activation of digestive enzymes, especially trypsin, leads to the digestion of the pancreas and causes acute inflammation of pancreas [2]. Trypsin is synthesized as trypsinogen, an inactive precursor, in the rough endoplasmic reticulum, and trypsinogen is always cosynthesized and packed with a pancreatic secretory trypsin inhibitor that inhibits its premature activation [2]. Intra-acinar trypsin activation was considered the key event in acute pancreatitis, and this trypsin centric hypothesis was supported by various observations [2]. Ninety percent of pancreas is composed of acinar cells which secrete digestive enzymes such as trypsin, chymotrypsin, and amylase for digestion of food in the small intestine [3]. The pancreas is heavily innervated by sympathetic and parasympathetic peripheral nerves and contains a dense network of blood vessels which regulate blood flow and modulate pancreatic secretion [3]. Pancreatic exocrine secretion is regulated by a variety of neurotransmitters, including acetylcholine, vasoactive intestinal peptide, gastrin releasing peptide, neuromedin $\mathrm{C}$, neurotensin, substance $\mathrm{P}$, calcitonin gene-related peptide, etc. [3].

Calcitonin gene-related peptide (CGRP) is a 37-amino acid neuropeptide that is present in central and peripheral neurons, especially the cell bodies and endings of sensory neurons [4]. CGRP plays a role in both physiological and pathological conditions. For example, CGRP is involved in various brain functions such as sensory, cognitive and motor activities, participates in various cardiovascular functions, including modulation of vascular tone, microvascular permeability, cell proliferation, apoptosis and inflammation, and were associated with migraine, vascular disorders associated with aging and Raynaud's phenomenon, cutaneous-neuroimmune, and arthritis [5]. In addition, the study of isolated, vascularly perfused pancreas showed that CGRP could inhibit exocrine secretion from the rat pancreas by an indirect, neurally mediated mechanism involving cholinergic-muscarinic transmission [6]. CGRP was also considered to maybe serve as a marker for ascending visceral sensory pathways in the human brain [7]. A previous study showed that the deleterious effect of sensory nerves deactivation on necrotizing pancreatitis induced by ischemia/reperfusion was partly reversed by administration of CGRP prior to ischemia/ reperfusion [8]. Therefore, it is extremely necessary to study the influence of CGRP on acute pancreatitis.

Acute pancreatitis (AP) can range from a mild, selflimiting disease that requires no more than supportive measures to severe disease with life-threatening complications [9]. In approximately $15 \%$ of cases, patient can develop severe pancreatitis with tissue damage (also called acute necrotizing pancreatitis), and the patient will be admitted to the intensive care unit for closer monitoring [10]. The severe form comprising about $20-30 \%$ of the patients was a life-threatening disease with hospital mortality rates of about 15\% [11]. The acute inflammatory response itself causes substantial tissue damage and may progress beyond the pancreas to a systemic inflammatory response syndrome, multiorgan failure, or death [12]. Pancreatic microcirculatory disturbances are known to play a pivotal role in the pathogenesis of severe necrotizing pancreatitis [13]. Thus, improving pancreatic microcirculation is a significant way to improve the prognosis of AP.

CGRP has a series of regulatory effects of the vascular system, and is considered the most potent vasodilator currently known [14]. Therefore, the role of CGRP in acute pancreatitis has been paid more attention. In previous studies, we found that the serum levels of trypsin and CGRP in patients with I-II, III, IVA and IVB acute pancreatitis were higher than controls [15]. To further verify the antagonistic effect of CGRP on inflammation and the protective effect of compensatory increase of CGRP on pancreatic tissue in patients with acute pancreatitis, we constructed a mouse model of acute pancreatitis and treated the corresponding mouse model with CGRP. CGRP can protect the normal perfusion of pancreatic blood flow by dilating blood vessels and maintain the normal excitation of sensory nerves to keep a certain tension of blood vessels in pancreas, which can significantly improve the blood circulation of the pancreas. Therefore, the study of the effects of CGRP on pancreatic microcirculation will provide a new ideas in the field of the treatment of acute pancreatitis.

\section{Materials and methods}

\section{Reagents}

Caerulein (\#HY-A0190), CGRP ( $\alpha$-CGRP, \#HY-P1462) and CGRP $(8-37)$ (CGRP receptor antagonist, \#HY-P1014) were purchased from MedChemexpress Co. (New Jersey, USA). Lipopolysaccharide (LPS, from 
Escherichia coli (O111:B4)) was purchased from Sigma-Aldrich Co. (St. Louis, Missouri, USA). Pentobarbital sodium (\#096956-001, for animal experiments only) was purchased from Beijing Huaye Huanyu Chemical Co. (Beijing, China). Anhydrous ethanol (\#10009218), xylene (\#10023418) and paraffin wax (\#69018961) were purchased from Sinopharm Chemical Reagent Co., Ltd (Shanghai, China). Hematoxylin-Eosin Staining Kit (\#PH0516), DAB Horseradish Peroxidase Color Development Kit (\#PH0417), 5\% BSA Blocking Buffer (\#PH0420), Phosphate Buffered Saline Powder (\#PH1403) and 4\% Paraformaldehyde Fixation (\#PH0427) were purchased from Phygene Life Sciences Co., Ltd (Fuzhou, China). Anti-CGRP antibody (\#ab47027), Goat Anti-Rabbit IgG H\&L (HRP, \#ab205718), Recombinant Anti-CD20 antibody (\#ab64088) and PE/R-Phycoerythrin Conjugation Kit (\#ab102918) were purchased from Abcom Co. (Cambridge, England).

\section{Preparation of stock solution}

The $1 \mathrm{mg}$ of caerulein was dissolved into $1 \mathrm{~mL}$ of sterilized normal saline to obtain $1 \mathrm{mg} / \mathrm{mL}$ of clarified stock solution. If caerulein could not be fully dissolved, the ultrasonic treatment was performed briefly for 10 min with less than $30^{\circ} \mathrm{C}$. The stock solution was kept at $-20^{\circ} \mathrm{C}$ after separately packed in enzyme-free sterile centrifuge tube to avoid repeated freezing-thawing. The $10 \mathrm{mg}$ of LPS was dissolved into $10 \mathrm{~mL}$ of sterilized normal saline with lightly swirl to obtain $1 \mathrm{mg} / \mathrm{mL}$ of clarified stock solution. The stock solution was kept in enzyme-free sterile centrifuge tube at $-20^{\circ} \mathrm{C}$ when not in use. The $1 \mathrm{mg}$ of CGRP/ $\mathrm{CGRP}_{(8-37)}$ was dissolved into $1 \mathrm{~mL}$ of sterilized normal saline to obtain $1 \mathrm{mg} / \mathrm{mL}$ of clarified stock solution, which was separately packed in enzyme-free sterile centrifuge tube and stored at $-80^{\circ} \mathrm{C}$.

\section{Grouping of experimental animals and establishment of acute pancreatitis model}

Animal experiments were performed in accordance with the Guideline for Animal Experimentation with the approval of the Animal Care and Use Committee of Putian University (No. PUACUC 2019-03011). In this study, the male $\mathrm{C} 57 / 6$ mice with healthy clean grade and 18-22 $\mathrm{g}$ of weight were purchased from Shanghai Shrek Laboratory Animal Company. All the mice were fed with a standard diet and fasted for $18 \mathrm{~h}$ before the induction of acute pancreatitis, and accessed to water ad libitum during the experiments. After weighing 40 mice separately, they were completely randomly divided into five groups, namely control group (Con), acute pancreatitis group (AP), CGRP pretreatment group (preCGRP+AP), CGRP treatment group $(\mathrm{CGRP}+\mathrm{AP})$ and $\mathrm{CGRP}_{(8-}$ 37) pretreatment group (preCGRP $\left.{ }_{(8-37)}+\mathrm{AP}\right)$. There were no less than eight mice in each group, and the number of mice in the corresponding groups was increased appropriately according to the experimental needs. In the experiment, the administration volume of $20 \mathrm{~mL} / \mathrm{kg}$ was used for intraperitoneal injection in mice [16]. All the injection doses mentioned herein represent a single dose, including $100 \mu \mathrm{g} / \mathrm{kg}, 10 \mathrm{mg} /$ $\mathrm{kg}$ and $50 \mathrm{mg} / \mathrm{kg}$. Details of each group were as follows [17]:

Con: the mice were intraperitoneally injected with sterile normal saline at a dose of $20 \mathrm{~mL} / \mathrm{kg}$ at a $1 \mathrm{~h}$ interval six times.

AP: the mice were intraperitoneally injected with caerulein at a dose of $100 \mu \mathrm{g} / \mathrm{kg}$ at a $1 \mathrm{~h}$ interval six times, and an intraperitoneal injection of LPS was administered at a dose of $10 \mathrm{mg} / \mathrm{kg}$ after the last intraperitoneal injection of caerulein.
preCGRP+AP: CGRP was intraperitoneally injected into the mice at a dose of $100 \mu \mathrm{g} / \mathrm{kg} 30 \mathrm{~min}$ before the first dose of caerulein.

CGRP+AP: CGRP was intraperitoneally injected into mice at a dose of $100 \mu \mathrm{g} / \mathrm{kg} 12 \mathrm{~h}$ after successive six doses of caerulein and one dose of LPS.

$\operatorname{preCGRP}_{(8-37)}+\mathrm{AP}: \mathrm{CGRP}_{(8-37)}(\mathrm{CGRP}$ receptor antagonist) was intraperitoneally injected into mice at a dose of $100 \mu \mathrm{g} / \mathrm{kg} 30 \mathrm{~min}$ before the first dose of caerulein.

\section{Treatment of CGRP on acute pancreatitis}

The mice were intraperitoneally injected with CGRP at a dose of $100 \mu \mathrm{g} / \mathrm{kg}$ in preCGRP+AP, CGRP+AP and preCGRP $(8-37)+\mathrm{AP}$ group, and the same dose of sterile normal saline in Con and AP group, $12 \mathrm{~h}$ after successive six doses of caerulein and one dose of LPS.

\section{Collection of serum and pancreatic tissue in mice}

According to the preparation method of acute pancreatitis model, six doses of caerulein and one doses of LPS were intraperitoneally injected successively, which successfully induced acute pancreatitis in mice. The blood in mice was collected in AP group 12 and $24 \mathrm{~h}$ after successive six doses of caerulein and one dose of LPS, respectively, and in preCGRP+AP, CGRP+AP and preCGRP ${ }_{(8-37)}+\mathrm{AP}$ group $12 \mathrm{~h}$ after treatment of CGRP. In Con group, the blood was collected 12 and $24 \mathrm{~h}$ after the mice were intraperitoneally injected with seven doses of sterile normal saline equal to six doses of caerulein and one dose of LPS. The collected blood method were as follows: the mice were anesthetized by intraperitoneal injection of pentobarbital sodium at a dose of $50 \mathrm{mg} / \mathrm{kg}$, and then the blood in the mice was harvested via retrobulbar plexus without anticoagulation [16]. The harvested blood samples were placed at $4^{\circ} \mathrm{C}$ for $1 \mathrm{~h}$, and then centrifuged at 3,500 rpm/ $\min$ for $10 \mathrm{~min}$, and the upper serums were collected to detect various biochemical indicators. The obtained serums were kept in the refrigerator at $-80^{\circ} \mathrm{C}$ when not in use. After blood collection, the experimental mice were euthanized and laparotomized, and then the mice were dissected to observe and record the changes in the pancreas. Meanwhile, the pancreas and surrounding tissues were observed to record edema, congestion, necrosis and other phenomena. The head tissue of pancreas was cut and fixed with $4 \%$ paraformaldehyde for preparation of pathological sections.

\section{Determination of activity of amylase and trypsin}

The activities of amylase and trypsin were determined by colorimetric method using amylase assay kit and trypsin assay kit, respectively. Assay kits of amylase (C016-1-1) and trypsin (A080-2-2) for mice were purchased from Nanjing Jiancheng Biological Products Institute (Nanjing, China). All materials and prepared reagents were equilibrated to room temperature prior to use. Each well was repeated three times in the experiment. The detailed experimental procedure is as follows:

Standard wells: The $50 \mu \mathrm{L}$ of standard solutions with different concentrations were added into different wells, which was used to draw standard curves.

Positive control wells: A $5 \mu \mathrm{L}$ of positive substrate was added into well and adjusted to $50 \mu \mathrm{L} /$ well with assay buffer. 
Sample wells: A $10 \mu \mathrm{L}$ of serum samples was add into well and adjusted to $50 \mu \mathrm{L} /$ well with assay buffer.

A $100 \mu \mathrm{L}$ of reaction mixture was added into each well and mixed thoroughly. The reaction mixture consists of assay buffer and substrate in a proportion of 1:1 for amylase and 14:1 for trypsin. The absorbance at $405 \mathrm{~nm}$ was immediately determined by a Microplate Reader after incubation for $30 \mathrm{~min}$ at $37^{\circ} \mathrm{C}$ in dark. Finally, the standard curves were drawn to calculate the activity of amylase and trypsin, respectively.

\section{Evaluation of pancreatic lesions}

After observing the appearance characteristics of the pancreas in the experimental mice, the head tissues of the pancreas, such as the size of green beans, were fixed with formaldehyde, embedded, sectioning and stained with HE, and the pathological changes were observed under an optical microscope. The total scores of pathological findings were derived from five items, including edema, hemorrhage, acinar necrosis, pancreatic duct lesion and inflammatory infiltration. Each item was rated on five scales, namely $0,1,20,30$, and 40 .

\section{Preparation of histological sections}

After fixed for more than $24 \mathrm{~h}$, the pancreatic tissues were removed from the fixing solution and trimmed to make the target site of the tissues smooth. And then, the tissues were dehydrated in the different dehydration boxes, which successively were $75 \%$ ethanol for $4 \mathrm{~h}$ $\rightarrow 85 \%$ ethanol for $2 \mathrm{~h} \rightarrow 95 \%$ ethanol for $1 \mathrm{~h} \rightarrow$ anhydrous ethanol for $30 \mathrm{~min} \rightarrow$ xylene for $10 \mathrm{~min} \rightarrow$ paraffin wax for $1 \mathrm{~h}$. Next, the waxed tissue was embedded and processed on the slicer to obtain $4 \mu \mathrm{m}$ of thick sections. The sections were flatted on a glass slide and baked at $60{ }^{\circ} \mathrm{C}$ for $30 \mathrm{~min}$. After the wax melted, the sections were successively placed in xylene for $20 \mathrm{~min} \rightarrow$ anhydrous ethanol for $5 \mathrm{~min} \rightarrow 75 \%$ ethanol for $5 \mathrm{~min} \rightarrow$ tap water for washing. Subsequently, hematoxylin-eosin (H\&E) staining and immunohistochemical staining were performed on the obtained sections.

\section{Hematoxylin-eosin (H\&E) staining}

The sections were stained with hematoxylin solution for $5 \mathrm{~min}$, and then rinsed with tap water. After the sections were placed into $1 \%$ hydrochloric acid for a few seconds and rinsed with tap water, $0.6 \%$ ammonia water was added to turn blue and tap water rinsed the sections. After that, the sections were stained with eosin solution for $5 \mathrm{~min}$, and then dehydrated, successively in anhydrous ethanol for $5 \mathrm{~min} \rightarrow$ xylene for $5 \mathrm{~min}$. Finally, the sections were sealed with neutral resin.

\section{Immunohistochemical staining}

The sections were immersed into $0.01 \mathrm{~mol} / \mathrm{L}$ citrate buffer solution and heated with microwave for $10 \mathrm{~min}$ to repair antigen. After cooling for $10 \mathrm{~min}$, the sections were heated for another $3 \mathrm{~min}$. Next, the sections were placed in $3 \% \mathrm{H}_{2} \mathrm{O}_{2}$ solution for $10 \mathrm{~min}$ to inactivate endogenous peroxidase activity, and then were sealed with $5 \%$ BSA blocking buffer at room temperature to block the non-specific adsorption of antibodies and reduce the background staining. After the excess BSA solution was discarded, $30 \mu \mathrm{L}$ of primary antibody solution was added onto the sections and incubated in a humidified box at $4^{\circ} \mathrm{C}$ overnight, followed by reheating at $37^{\circ} \mathrm{C}$ for $20 \mathrm{~min}$ and soaking in PBS buffer for $5 \mathrm{~min}$ repeatedly three times. After that, $30 \mu \mathrm{L}$ of biotinylated secondary antibody solution was added onto the sections and incubated at $37^{\circ} \mathrm{C}$ for $60 \mathrm{~min}$, followed by soaking in PBS buffer for $5 \mathrm{~min}$ repeatedly three times. The sections were developed by DAB Immunohistochemistry Color Development Kit at room temperature for $10 \mathrm{~min}$, rinsed with tap water, and then redyed with hematoxylin for $1 \mathrm{~min}$. After washing, the sections were dehydrated, transparent and sealed with neutral resin.

\section{Image acquisition}

The images of the sections of H\&E staining and immunohistochemical staining were acquired on an optical microscope (Nikon Eclipse E100, Japan).

\section{Statistical analysis}

The statistical analyses were carried out by GraphPad Prism 6.0 (GraphPad Software, San Diego, CA). One-way ANOVA was used for multiple comparisons and was followed by Bonferroni's test. Statistical differences with $\mathrm{p}$ values less than 0.05 were considered significant. All data were represented as the mean \pm standard deviation (SD) from eight parallel independent experimental results.

\section{Results}

\section{Morphological characteristics of pancreas and activity of trypsin and amylase in mice with AP}

After the mice were successively intraperitoneally injected with six doses of caerulein and one dose of LPS for $12 \mathrm{~h}$, the volume of pancreas increased, the texture of pancreas was slightly hard, the boundary structure was blurred, and there was obvious swelling and hyperemia in pancreas. The head and tail of pancreas showed the most prominent edema and dark red color. Saponification spots occurred on the pancreas surface. There was a small amount of fluid in the abdominal cavity of mice with AP, obvious saponification spots occurred in the mesentery and omentum, and the pancreas had a severe adhesion to the surrounding tissues.

The experimental results in Figure 1A showed that the activity of trypsin in AP group increased significantly compared with Con group. The activity of trypsin in Con group was 5,550 $\pm 860 \mathrm{U} / \mathrm{L}$, and the activity of trypsin in AP group for 12 and $24 \mathrm{~h}$ were 7,810 $\pm 1,021$ and $9,396 \pm 1354 \mathrm{U} / \mathrm{L}$, respectively. The activity of trypsin in AP group was significantly stronger than that in Con group 
$\left({ }^{\star \star} \mathrm{p}<0.01\right)$. In addition, the activity of trypsin in AP group for $24 \mathrm{~h}$ was significantly higher than AP group for $12 \mathrm{~h}$ $\left({ }^{\star} \mathrm{p}<0.05\right)$. The experimental results in Figure 1B showed that the activity of amylase in AP group for 12 and $24 \mathrm{~h}$ was obviously higher than that in Con group $\left({ }^{\star \star} \mathrm{p}<0.01\right)$. The activity of amylase in AP group for 12 and $24 \mathrm{~h}$ were $14,263 \pm 1,491$ and $16,393 \pm 1180 \mathrm{U} / \mathrm{L}$, respectively, and the activity of amylase in Con group was 4,549 $\pm 670 \mathrm{U} / \mathrm{L}$. And the activity of amylase in AP group for $24 \mathrm{~h}$ was also significantly higher than that in AP group for $12 \mathrm{~h}\left({ }^{\star} \mathrm{p}<0.05\right)$.

The above results suggested that the mice model with AP induced by caerulein combining with lipopolysaccharide were successfully established.

\section{Pancreatic histopathology in mice with AP}

The typical pathologic feature of pancreatic tissue in Con group was shown in Figure 2A. The boundaries of pancreatic tissue were clear and uniform in color. The lobules were complete in structure and normal in shape, and there was no infiltration of neutrophils and erythrocytes and no obvious edema. The pancreatic acini was also well defined and had a complete structure, and the staining of cytoplasm and nucleoli was clearly visible, without bleeding or necrosis. The pancreatic tissues of mice in AP group were observed under light microscope. As can be seen from Figure 2B, the total volume of the pancreas was larger than that of Con group, and the structure of the glands was more disordered, there was marked edema and rupture of the acinus in pancreas, and the outline was not clear. The nucleus is partially pyknotic (green arrow), and inflammatory cells infiltrated (yellow arrow), and there was the exudation of red blood cells around the blood vessels and between the glands (blue arrow).

\section{Evaluation results of pancreatic lesions}

In AP group, the pancreatic duct was swollen, the color was deepened, the pancreas was hyperemic, and there were scattered brown necrotic foci and a small amount of bloody ascites, and mesenteric edema was obvious, $12 \mathrm{~h}$ after intraperitoneal injection of successive six doses of
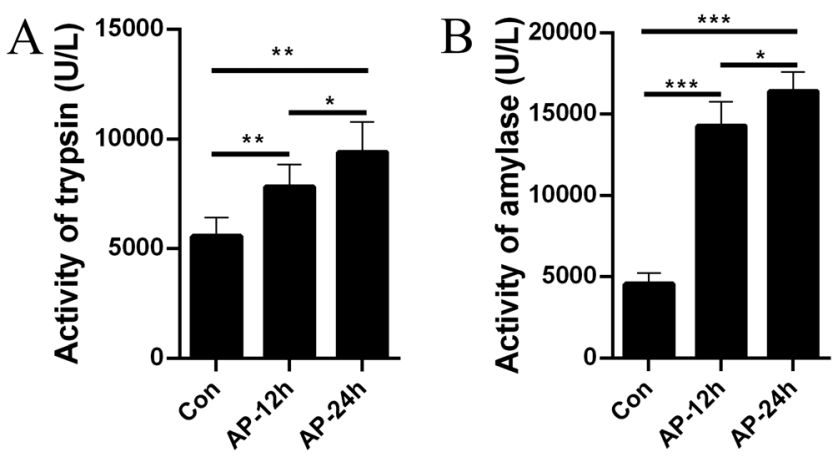

Figure 1: Comparison of activity of trypsin and amylase in serum between Con group and AP group. The activity of trypsin and amylase in Con group and AP group was measured at 12 and $24 \mathrm{~h}$, respectively. In Con group, there was no significant difference in the activity of trypsin and amylase during the whole experiment process, so it was shown as a set of data in the figure. One-way ANOVA was performed with Bonferroni's test to identify the significant difference between multiple groups. The error bars represents standard deviation and reflects the dispersion of the data. ${ }^{*} p<0.05,{ }^{* \star} p<0.01$, and ${ }^{\star * \star} p<0.001$.
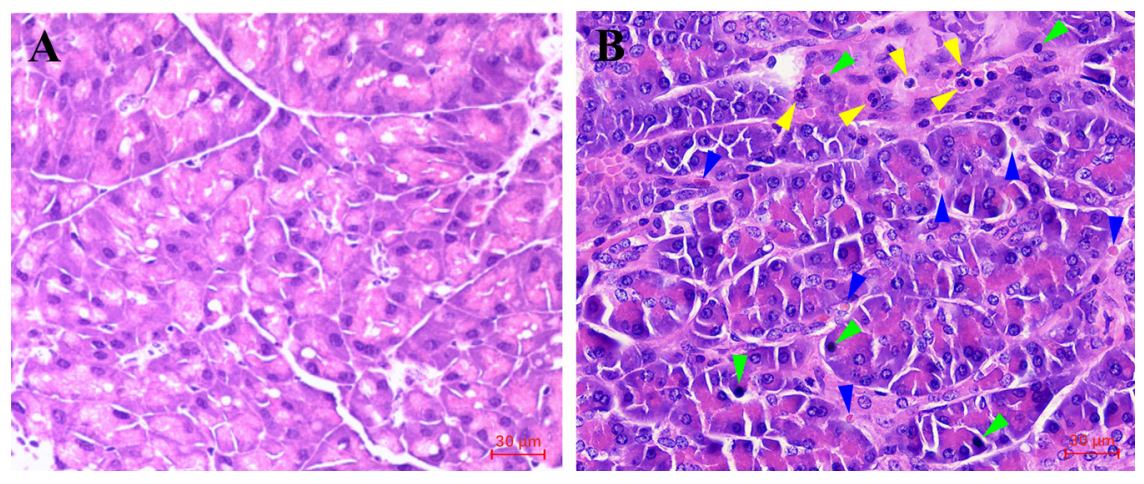

Figure 2: Representative micrographs of H\&E-stained pancreatic histopathological sections in mice $(\times 400)$. A and $B$ were Con group and AP group, respectively. Green, yellow and blue arrow indicated nucleuspyknotic cell, inflammatory cell and red blood cells, respectively. 
caerulein and one dose of LPS. In preCGRP+AP and CGRP + AP group, the pancreas of the mice showed acini necrosis, but the degree of necrosis was significantly less severe than AP group. The pathological scores of the pancreas in each group were shown in Table 1. In preCGRP $(8-37)+\mathrm{AP}$ group, both each score and total scores were the highest in all the groups, and the pathological changes were significantly worse than those in preCGR$\mathrm{P}+\mathrm{AP}$ and $\mathrm{CGRP}+\mathrm{AP}$ group. The total scores were close to each other in preCGRP+AP and CGRP+AP group, and the difference between preCGRP $+\mathrm{AP}$ and $\mathrm{CGRP}+\mathrm{AP}$ group was not significant. Whether it's preCGRP+AP/CGRP+AP group vs. AP group, or preCGRP+AP/CGRP+AP group vs. pre-CGRP ${ }_{(8-37)}+\mathrm{AP}$ group, there were significant differences among the total scores $(\mathrm{p}<0.05)$, as shown in Table 1. The score of inflammatory infiltration in Table 1 showed that the pancreatic inflammation of mice in pre$\mathrm{CGRP}_{(8-37)}+\mathrm{AP}$ group was more severe than AP group. Thus, the experiment confirmed the protective effect of CGRP on pancreatic injury from positive and negative aspects.

\section{Amylase of mice in different groups}

As shown in Figure 3, the activity of amylase in AP group was $16,393 \pm 1180 \mathrm{U} / \mathrm{L}$ and significantly higher than that in Con group $\left(4,549 \pm 670 \mathrm{U} / \mathrm{L},{ }^{\star \star} \mathrm{p}<0.01\right)$. In the CGRP intervention study, we found that the activity of amylase was $5,012 \pm 788$ and 5,610 $\pm 866 \mathrm{U} / \mathrm{L}$ in preCGRP + AP and CGRP+AP group, respectively, and had no significant difference between preCGRP+AP and $\mathrm{CGRP}+\mathrm{AP}$ group $(p=0.1103)$. And there was no significant difference of amylase activity between the two groups and Con group (preCGRP+AP vs. Con: $\mathrm{p}=0.3033$; $\mathrm{CGRP}+\mathrm{AP}$ vs. Con: $\mathrm{p}=0.0517)$. The activity of amylase in $\operatorname{preCGRP}_{(8-37)}+\mathrm{AP}$ group was $15,902 \pm 1685 \mathrm{U} / \mathrm{L}$ and significantly higher than that in Con, preCGRP $+\mathrm{AP}$ and CGRP+AP $\left({ }^{\star \star \star} \mathrm{p}<0.001\right)$. However, there was no significant difference for the activity of amylase between preCGRP ${ }_{(8-37)}+\mathrm{AP}$ and AP group $(\mathrm{p}=0.3764)$.

\section{Expression of CGRP in different groups}

We analyzed the expression of CGRP in pancreatic tissues of mice in different groups by immunohistochemistry. Figure 4A showed that CGRP was low expressed in pancreatic tissue of Con group. However, pancreatic tissue of AP group showed significant expression of CGRP,

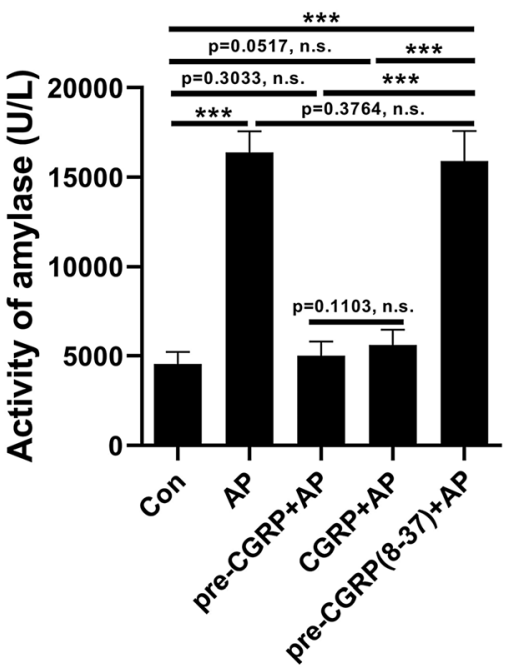

Figure 3: Comparison of amylase activity in Con, $A P$, preCGRP+AP, $C G R P+A P$, and preCGRP $(8-37)+A P$ group. The activity of amylase was measured in Con and AP group $24 \mathrm{~h}$ after induction of $A P$, and in preCGRP+AP, CGRP+AP and preCGRP $(8-37)+\mathrm{AP}$ group $12 \mathrm{~h}$ after treatment of CGRP. One-way ANOVA was performed with Bonferroni's test to identify the significant difference between multiple groups. The error bars represents standard deviation and reflects the dispersion of the data. ${ }^{\star \star *} p<0.001 ;$ n.s., no significance; $p>0.05$.

Table 1: Evaluation results of pancreatic lesions in different groups*.

\begin{tabular}{|c|c|c|c|c|c|c|}
\hline Groups $(n=8)$ & Edema & Hemorrhage & Acini necrosis & Pancreatic duct lesion & Inflammatory infiltration & Total scores \\
\hline Con & $3 \pm 1.31$ & $4 \pm 1.04$ & 0 & 0 & 0 & $7 \pm 2.34$ \\
\hline AP & $10 \pm 2.87$ & $11 \pm 2.92$ & $17 \pm 4.66$ & $1 \pm 0.83$ & $22 \pm 6.47$ & $61 \pm 17.74$ \\
\hline pre-CGRP+AP & $8 \pm 2.62$ & $12 \pm 3.74$ & $10 \pm 3.89$ & $0 \pm 0.52$ & $8 \pm 3.74$ & $38 \pm 14.51^{\mathrm{a}, \mathrm{b}}$ \\
\hline $\mathrm{CGRP}+\mathrm{AP}$ & $9 \pm 4.14$ & $11 \pm 3.58$ & $10 \pm 4.22$ & $0 \pm 0.74$ & $9 \pm 3.54$ & $39 \pm 16.23^{c, d}$ \\
\hline pre-CGRP $(8-37)+A P$ & $10 \pm 2.45$ & $11 \pm 3.46$ & $18 \pm 5.48$ & $1 \pm 0.74$ & $26 \pm 7.21$ & $66 \pm 19.34$ \\
\hline
\end{tabular}

All data were mean \pm standard deviation for eight parallel assays. ${ }^{*}$ The statistical comparison in Table 1 was mainly the comparison of total scores between groups. The total score for each group was derived from the sum of the five scores, including edema, bleeding, acini necrosis, pancreatic duct lesion and inflammatory infiltration. One-way ANOVA was performed with Bonferroni's test to identify the significant difference between multiple groups. ${ }^{\mathrm{a}}$ pre-CGRP+AP vs. AP, $p<0.05$; ${ }^{\mathrm{b}}$ pre-CGRP+AP vs. pre-CGRP $(8-37)+A P, p<0.05 ;{ }^{\mathrm{c}} \mathrm{C} G R P+A P$ vs. $A P, p<0.05 ;{ }^{d} C G R P+A P$ vs. pre-CGRP ${ }_{(8-37)}+A P, p<0.05$. 
which was the dark brown within the green dotted line in Figure 4B. In preCGRP+AP and CGRP+AP group, CGRP was strongly high expressed in pancreatic tissue and distributed in clusters, as shown the dark brown within the green dotted line in Figure 4C, D. Unexpectedly, after

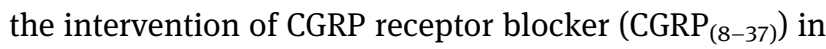
advance, the expression of CGRP was low or weak in $\operatorname{preCGRP}_{(8-37)}+$ AP group (Figure 4E), which was similar to the expression of CGRP in Con group.

\section{Influence of CGRP on inflammatory cells in different groups}

Figure $5 \mathrm{~A}$ showed that there was no $\mathrm{CD} 20^{+} \mathrm{B}$ lymphocytes in Con group. In stark contrast, a lot of $\mathrm{CD}_{2} \mathrm{O}^{+} \mathrm{B}$ lymphocytes were present in the pancreatic tissue of AP group (Figure 5B), indicating that humoral immunity was involved in the pathological process of AP. Figures 5C, D showed that $\mathrm{CD}_{2} \mathrm{O}^{+}$B lymphocytes were significantly
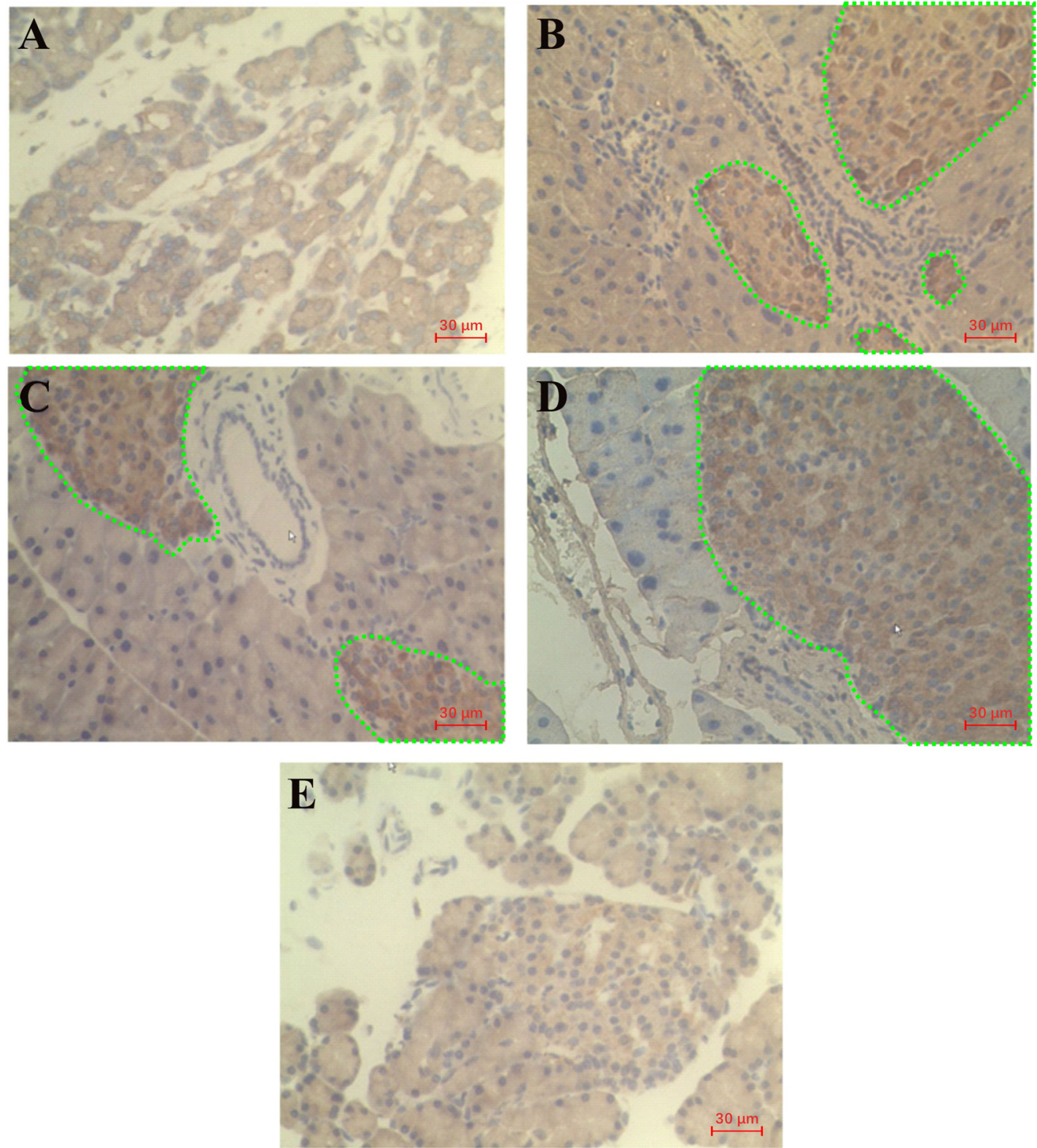

Figure 4: Representative micrographs of immunohistochemistry-stained pancreatic histopathological sections in mice $(\times 400)$. A, B, C, D and E were Con group, AP group, preCGRP+AP group, $C G R P+A P$ group, and preCGRP $(8-37)+A P$ group, respectively. The dark brown within the dotted green line represented the high expression of CGRP. 

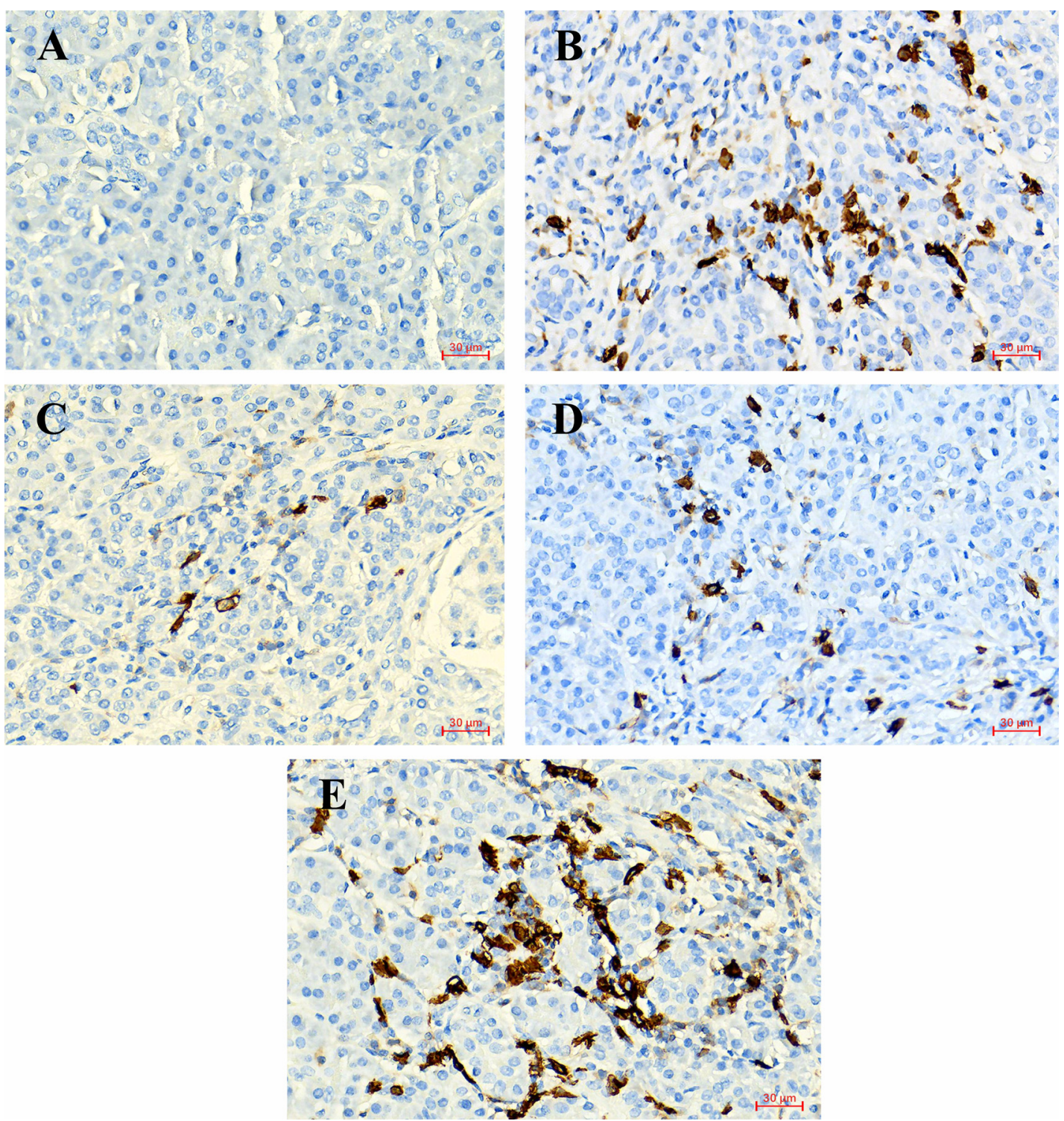

Figure 5: Representative micrographs of immunohistochemistry-stained pancreatic histopathological sections in mice $(\times 400) . A, B, C, D$, and E were Con group, AP group, preCGRP+AP group, $C G R P+A P$ group and preCGRP $(8-37)+A P$ group, respectively. The dark brown represented the infiltration of $\mathrm{CD} 20^{+} \mathrm{B}$ lymphocytes in pancreatic tissue.

reduced in preCGRP+AP and $\mathrm{CGRP}+\mathrm{AP}$ group, respectively. However, many $\mathrm{CD} 2 \mathrm{O}^{+} \mathrm{B}$ lymphocytes appeared in the pancreatic tissue of preCGRP $(8-37)+\mathrm{AP}$ group (Figure 5E), which was similar to AP group.

\section{Discussion}

Acute pancreatitis (AP) is an inflammatory process which causes a local and systemic inflammatory response syndrome (SIRS), and around $20 \%$ of patients will develop moderate or severe pancreatitis, with necrosis of the (peri) pancreatic tissue and/or (multiple-) organ failure [18].
At present, numerous therapeutic options of AP have been explored, but there is a lack of etiological treatment, and symptomatic and supportive treatment remains the only therapy. Some studies have suggested that improving pancreatic microcirculation may be an option for the treatment of AP. For example, Keck et al. confirmed that oxygen radical scavenger (dimethylsulfoxide) improved the pancreatic microcirculation to consequently significantly interfere with the pathogenesis of acute pancreatitis [19]; Strate et al. demonstrated that the therapeutic intravenous infusion of bovine hemoglobin improved pancreatic microcirculation and reduced pancreatic tissue damage in severe acute rodent pancreatitis [20]; Mann et al. 
showed that small-volume resuscitation preserved capillary microcirculation and prevented pancreatic injury in intermediate necrotizing pancreatitis [21]; and Tomkötter et al. found that pancreatic microcirculatory disturbances had significant effects on histopathologic tissue damage and the outcome of severe acute pancreatitis [22]. In addition, impairment and constriction of pancreatic intralobular arteriolar sphincter were the initial microcirculatory lesions in the early phase of AP, and played a key role in the pancreatic ischemia and pancreatic microvascular failure in AP [23]. Thus, the research on the relationship between pancreatic microcirculation and AP has been paid more and more attention, and the change of microcirculation is one of the initial factors of AP.

Calcitonin gene-related peptide (CGRP), a potent vasodilator neuropeptide, could protect myocardium against damage evoked by ischemia reperfusion bind [24]. Saeki et al. considered that PGI2 enhancing the release of CGRP eliminated constrictions of collecting venules and venules, mediating $0.1 \mathrm{~mol} / \mathrm{L} \mathrm{NaCl}$ to prevent ethanolinduced gastric mucosal microcirculatory disturbances in rats [25]. Furthermore, the vasodilator effect of exogenous CGRP in human skin suggested that this peptide directly or indirectly induced a smooth muscle vascular cells and sympathetic fibers stimulation [26]. Zhang et al. found that amygdalin alleviated pancreatic fibrosis and acinar destruction in rats with chronic pancreatitis, the mechanism of which included improving microcirculatory disturbance by up-regulating the expression of CGRP [27]. Meanwhile, we found that the level of CGRP significantly increased in serum of patients with AP, and considered that it may be a protective compensatory response [15]. Therefore, the influence of CGRP on AP was further studied in this study.

In this study, we successfully established the model mice with AP by intraperitoneal injection of successive six doses of caerulein and one dose of LPS, and verified the activity of trypsin and amylase in serum of mice (Figure 1) and the H\&E-stained section of pancreatic tissue (Figure 2), laying a good foundation for further research on the influence of CGRP on AP.

In the evaluation of the degree of pancreatic lesions, Table 1 showed that pancreatic hyperemia and necrosis obviously happened in all the group except Con group, but the degree in preCGRP+AP and $\mathrm{CGRP}+\mathrm{AP}$ group was less than that in $\mathrm{AP}$ and preCGRP ${ }_{(8-37)}+\mathrm{AP}$ group, suggesting that intraperitoneal injection of CGRP significantly improved the pancreatic lesions in mice with AP. The inflammatory infiltration was more severe in preCGRP ${ }_{(8-37)}+\mathrm{AP}$ group than in preCGRP+AP and CGRP+AP group, indicating that CGRP reduced inflammation of the pancreas with AP. In addition, after the injection of CGRP receptor antagonist, the sensitivity of the microvessel to the action of CGRP decreased, making it unable to play a role. This may be because CGRP inhibited the secretion of macrophages and had the ability to activate $\mathrm{T}$ cells, producing an anti-inflammatory effect [28]. And Raud et al. found that CGRP, but not substance P (SP), could inhibit edemapromoting actions of inflammatory mediators (histamine, leukotrine B4, 5-hydroxytryptamine) in vivo in the hamster cheek pouch, human skin, and rat paw [29]. The activity of amylase in AP and preCGRP ${ }_{(8-37)}+\mathrm{AP}$ group was higher than that in Con, preCGRP+AP and CGRP+AP group, and there was no significant difference between preCGRP+AP/ CGRP+AP group and Con group, as shown in Figure 3, reflecting that CGRP reduced the damage of pancreatic acinar cells. Immunohistochemical results in Figure 4 showed that CGRP was significantly highly expressed in $\mathrm{AP}$, preCGRP+AP and CGRP+AP group, which further confirmed that CGRP had a compensatory protective response for pancreas during the occurrence of AP. Meanwhile, the intervention of CGRP reduced the expression of $\mathrm{CD}_{20}{ }^{+} \mathrm{B}$ lymphocytes in preCGRP+AP and CGRP+AP group, as shown in Figures 5C, D, suggesting that CGRP could reduce the inflammation in pancreatic tissues with AP. In contrast, the pre-intervention of CGRP receptor antagonist $\left(\mathrm{CGRP}_{(8-37)}\right)$ could decrease the expression of CGRP (Figure 4E) and increase the number of $\mathrm{CD}_{20}{ }^{+} \mathrm{B}$ lymphocytes (Figure 5E) in preCGRP ${ }_{(8-37)}+\mathrm{AP}$ group, thus reversely confirming the protective effect of CGRP on pancreatic tissues with AP. All the experimental results confirmed the protective effect of CGRP on pancreatic injury in both positive and negative aspects. The possible mechanism is that CGRP can increase the blood flow and flow velocity of pancreatic microcirculation and reduce the permeability of microvessels, thus improving the pancreatic microcirculation and alleviating the pathological damage of pancreatic tissues during AP.

\section{Conclusion}

In this study, we observed that intraperitoneal injection of CGRP can significantly improve the pancreatic lesions and inflammatory infiltration of pancreas in mice with AP, and reduce the damage of pancreatic acinar cells. This may be because CGRP improves the pancreatic microcirculation by increasing blood flow and blood flow velocity of the pancreas, reduces the permeability of the microvessels and other comprehensive effects, and effectively decreases the pathological damage degree of AP. Since CGRP is secreted by nerves, plays a role, and increases vascular permeability, there is still a debate on whether CGRP can improve vascular 
permeability while dilating vessels. In a word, this study provides a possible new option for the treatment of AP and lays the foundation for studying the influence of CGRP on AP.

Research funding: This study was financially supported by the Natural Science Foundation of Fujian Province (2017J01346, 2018J01195), and Fujian Province Medical Health Young and Middle-aged Talents training Project (2020GGA079).

Author contributions: All authors have accepted responsibility for the entire content of this manuscript and approved its submission.

Competing interest: All authors declared that there were not any potential conflicts of interest.

Ethical approval: Animal experiments were performed in accordance with the Guideline for Animal Experimentation with the approval of the Animal Care and Use Committee of Putian University (No. PUACUC 2019-03011).

\section{References}

1. Longnecker DS. Anatomy and histology of the pancreas (Version 2.0). Pancreapedia: Exocrine Pancreas Knowledge Base, 2014. https://doi.org/10.3998/panc.2014.3.

2. Dixit A, Dawra RK, Dudeja V, Saluja AK. Role of trypsinogen activation in genesis of pancreatitis (Version 1.0). Pancreapedia: Exocrine Pancreas Knowledge Base, 2016. https://doi.org/10. 3998/panc.2016.25.

3. Chandra R, Liddle RA. Regulation of pancreatic secretion (Version 2.0). Pancreapedia: Exocrine Pancreas Knowledge Base, 2015. https://doi.org/10.3998/panc.2020.14.

4. Russell FA, King R, Smillie SJ, Kodji X, Brain SD. Calcitonin generelated peptide: physiology and pathophysiology. Physiol Rev 2014;94:1099-142.

5. Aubdool AA, Kodji X, Brain SD. Calcitonin gene-related peptide (CGRP). In: Huhtaniemi I, Martini L, editors. Encyclopedia of endocrine diseases, 2nd ed. New York: Academic Press, 2017, vol 4: 204-12 pp.

6. Bunnett NW, Mulvihill SJ, Debas HT. Calcitonin gene-related peptide inhibits exocrine secretion from the rat pancreas by a neurally mediated mechanism. Exp Physiol 1991;76:115-23.

7. de Lacalle S, Saper CB. Calcitonin gene-related peptide-like immunoreactivity marks putative visceral sensory pathways in human brain. Neuroscience 2000;100:115-30.

8. Dembiński A, Warzecha Z, Ceranowicz P, Jaworek J, Sendur R, Knafel A, et al. Stimulation of sensory nerves and CGRP attenuate pancreatic damage in ischemia/reperfusion induced pancreatitis. Med Sci Monitor 2003;9:BR418-25.

9. Greenberg JA, Hsu J, Bawazeer M, Marshall J, Friedrich JO, Nathens A, et al. Clinical practice guideline: management of acute pancreatitis. Can J Surg 2016;59:128-40.

10. Afghani E. Introduction to pancreatic disease: acute pancreatitis (Version 1.0). Pancreapedia: Exocrine Pancreas Knowledge Base, 2014. https://doi.org/10.3998/panc.2014.14.
11. Leppäniemi A, Tolonen M, Tarasconi A, Segovia-Lohse H, Gamberini E, Kirkpatrick AW, et al. 2019 WSES guidelines for the management of severe acute pancreatitis. World J Emerg Surg 2019;14:27.

12. Whitcomb DC. Acute pancreatitis. N Engl J Med 2006;354: 2142-50.

13. Schneider L, Hartwig W, Flemming T, Hackert T, Fortunato F, Heck $M$, et al. Protective effects and anti-inflammatory pathways of exogenous calcitonin gene-related peptide in severe necrotizing pancreatitis. Pancreatology 2009;9:662-9.

14. Brain SD, Williams TJ, Tippins JR, Morris HR, MacIntyre I. Calcitonin gene-related peptide is a potent vasodilator. Nature 1985;313:54-6.

15. Hu JX, Lin W, Zhao CF, Chen JF. The relationship between trypsin/ calcitonin gene related peptide (CGRP) in serum and acute pancreatitis (AP). Clin Lab 2018;64:93-7.

16. Diehl KH, Hull R, Morton D, Pfister R, Rabemampianina Y, Smith D, et al. A good practice guide to the administration of substances and removal of blood, including routes and volumes. J Appl Toxicol 2001;21:15-23.

17. Ding SP, Li JC, Jin C. A mouse model of severe acute pancreatitis induced with caerulein and lipopolysaccharide. World J Gastroenterol 2003;9:584-9.

18. van Dijk SM, Hallensleben ND, van Santvoort HC, Fockens P, van Goor H, Bruno MJ, et al. Acute pancreatitis: recent advances through randomised trials. Gut 2017;66:2024-32.

19. Keck T, Werner J, Banafsche R, Stalmann A, Schneider L, Gebhard MM, et al. Oxygen radicals promote ICAM-1 expression and microcirculatory disturbances in experimental acute pancreatitis. Pancreatology 2003;3:156-63.

20. Strate T, Mann O, Kleinhans H, Rusani S, Schneider C, Yekebas E, et al. Microcirculatory function and tissue damage is improved after therapeutic injection of bovine hemoglobin in severe acute rodent pancreatitis. Pancreas 2005;30:254-9.

21. Mann O, Kaifi J, Bloechle C, Schneider CG, Yekebas E, Kluth D, et al. Therapeutic small-volume resuscitation preserves pancreatic microcirculation in acute experimental pancreatitis of graded severity in rats. Pancreatology 2009;9: 652-61.

22. Tomkötter L, Erbes J, Trepte C, Hinsch A, Dupree A, Bockhorn M, et al. The effects of pancreatic microcirculatory disturbances on histopathologic tissue damage and the outcome in severe acute pancreatitis. Pancreas 2016;45:248-53.

23. Zhou ZG, Chen YD, Sun W, Chen Z. Pancreatic microcirculatory impairment in experimental acute pancreatitis in rats. World J Gastroenterol 2002;8:933-6.

24. Homma S, Kimura T, Sakai S, Yanagi K, Miyauchi Y, Aonuma K, et al. Calcitonin gene-related peptide protects the myocardium from ischemia induced by endothelin-1: intravital microscopic observation and 31P-MR spectroscopic studies. Life Sci 2014;118: 248-54.

25. Saeki T, Ohno T, Kamata K, Arai K, Mizuguchi S, Katori M, et al. Mild irritant prevents ethanol-induced gastric mucosal microcirculatory disturbances through actions of calcitonin generelated peptide and PGI2 in rats. Am J Physiol-Gastr L 2004;286: G68-75.

26. Rossi M, Carpi A, Maria CD, Galetta F, Santoro G. Skin microcirculatory effect of exogenous calcitonin gene-related peptide (CGRP) evaluated by laser Doppler flowmetry coupled 
with iontophoresis in healthy subjects. Microvasc Res 2007;73: 124-30.

27. Zhang XQ, Hu JG, Zhuo YZ, Cui LH, Li CX, Cui NQ, et al. Amygdalin improves microcirculatory disturbance and attenuates pancreatic fibrosis by regulating the expression of endothelin-1 and calcitonin gene-related peptide in rats. J Chin Med Assoc 2017;81: 437-43.
28. Springer J, Geppetti P, Fischer A, Groneberg DA. Calcitonin generelated peptide as inflammatory mediator. Pulm Pharmacol Therapeut 2003;16:121-30.

29. Raud J, Lundeberg T, Brodda-Jansen G, Theodorsson E, Hedqvist P. Potent anti-inflammatory action of calcitonin gene-related peptide. Biochem Bioph Res Co 1991;180: 1429-35. 